\begin{tabular}{lc}
\hline CURRENT & ISSN: 0973-4929, Vol. 12, No. (2) 2017, Pg. 204-210 \\
WORLD & Current World Environment
\end{tabular}

\title{
Heavy Metal Accumulation in Two Macrophyte Species in River Drina, Republic of Serbia
}

\author{
HALIME MABROUK SHAEBAN ELGAMOUDI and GORDANA DRAZIC* \\ Singidunum University, Faculty for Applied Ecology Futura, Belgrade, Republic of Serbia
}

\begin{abstract}
Monitoring of the state of the environment in the waterway itself and in the entire catchment area is important for its sustainable development. Heavy metals are strong environmental pollutants and many of them are toxic, even at very low concentrations. In this study River Drina was chosen due to these unique characteristics: the great river with large auto purification ability but in pressure of anthropogenic activities including hydropower plants, border between countries. The aim of this research was to compare data from chemical analyses of $\mathrm{Ni}, \mathrm{Zn}, \mathrm{Cu}, \mathrm{Cr}, \mathrm{Cd}, \mathrm{As}, \mathrm{Pb}$ and $\mathrm{Hg}$ contents in water, suspended solids and sediment with its contents in native macrophytes, Myriophyllum spicatum, and Potamogeton pusillus, in reservoirs of hydropower plants Bajina Bašta and Zvornik, on river Drina in Republic of Serbia. Contents of heavy metals in water were low and belongs to water class I. Heavy metal concentrations exceeds the limit values for $\mathrm{Ni}$ (184 $\mathrm{mg} / \mathrm{kg}), \mathrm{Zn}(3233 \mathrm{mg} / \mathrm{kg}), \mathrm{Cd}(0.0042 \mathrm{mg} / \mathrm{kg}), \mathrm{Cu}(157 \mathrm{mg} / \mathrm{kg})$ and As (109 $\mathrm{mg} / \mathrm{kg}$ ) in Zvornik reservoir in suspended solids and sediment and for $\mathrm{Zn}$ (1048 mg/kg), Cu (402 mg/kg) and Hg (2.24 mg/kg) in Bajina Bašta reservoir, in suspended solids. In all the examined cases heavy metal contents in macrophytes were significantly higher than in water and relationship with suspended solids and sediment depends to plant species and metal. For $\mathrm{Ni}$, $\mathrm{Cd}$ and As accumulation was obseved only in Myriophyllum spicatum, for $\mathrm{Cu}$ and $\mathrm{Pb}$ in both types. The obtained results indicate the need for further monitoring of the concentration of heavy metals in macrophytes, as well as sediment and suspended solids, in order to indicate and assess the quality of the aquatic ecosystem.
\end{abstract}

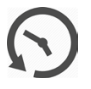

Article History

Received: 21 July 2017

Accepted:19 August 2017

\section{Keywords}

hydropower plant reservoir, monitoring,

Myriophyllum spicatum,

Potamogeton pusillus, suspended solids,

sediment,

water quality.

\section{Introduction}

Monitoring of the state of the environment in the waterway itself and in the entire catchment area is an important tool that should enable decision-makers to correctly determine the priorities in Environmental Management Plans to achieving benefits for its sustainable development ${ }^{1,2,3,4,5}$.
The Drina River basin extends to 4 countries (Albania, Montenegro, Bosnia and Herzegovina and Serbia), and the state border between Serbia and Bosnia and Herzegovina is located in the middle and lower water course of the river. As the largest tributary of the Sava River, it belongs to the Danube Basin that flows into the Black Sea. In its basin,

CONTACT GORDANA DRAZIC gordana.drazic@futura.edu.rs 9 Singidunum University, Faculty for Applied Ecology Futura,

Belgrade, Republic of Serbia

(C) 2017 The Author(s). Published by Enviro Research Publishers

This is an 6 Open Access article licensed under a Creative Commons Attribution-NonCommercial-ShareAlike 4.0 International License (https://creativecommons.org/licenses/by-nc-sa/4.0/ ), which permits unrestricted NonCommercial use, distribution, and reproduction in any medium, provided the original work is properly cited.

To link to this article: http://dx.doi.org/10.12944/CWE.12.2.03 
there are about one million inhabitants who have a significant pressure on the aquatic ecosystem with their activities (mining, industry, agriculture, rural and urban settlements) ${ }^{6}$.

In the Drina River Basin there are about 80 official hydrological stations within which regular measurements of water flow and levels are performed, the precipitation regime is monitored by 164 rain stations, then the air temperatures are at 26 meteorological stations, while other meteorological parameters are measured at significantly lower number of stations ${ }^{7}$. The River Drina is characterized mainly by peak flows during the spring months caused by snow melting and spring rains. On the other hand, during the summer months, the minimum flows (August and September) and the uneven (time and space) autumn maximum are characteristic. Hydrological characteristics of the Drina River are significantly influenced by hydroelectric dams ${ }^{8}$, two of which are in Serbia: Hydropower plant (HPP) Bajina Bašta and HPP Zvornik. According to the Ordinance on the Determination of Water Bodies of Surface and Ground Water (Official gazete RS, 96/2010) The Drina is categorized as a significantly modified water body. According to the Ordinance on parameters of ecological, chemical and quantitative status of surface and groundwater (Official gazete RS, 74/2011) The Drina is classified as type 2 - the great river, the dominance of the middle layer.

The Drina is a mountain watercourse with a great fall and great power of auto purification ${ }^{9}$, and as a result its waters are mainly in the second class of river water quality according to official monitoring of Hydro-Meteorological Service of the Republic of Serbia for 2015. However, this monitoring includes physical and chemical parameters of water, including the concentration of heavy metals as hazardous substances, and does not include sediment and suspended solids analysis, as well as an analysis of heavy metals (HM) content in biota.

Physicochemical characteristics of river water quality are changed by combined interactive processes of hydrology, topography, catchment area use, edaphic factors, erosion, bedrock geology, in combination with environmental influence of anthropogenic factors as well as living organisms in water and whole river basin ${ }^{10}$. Heavy metals as toxic for plants, animals and humans represents a big threat if they are in high concentration ${ }^{11}$. Toxic metals that can be accumulated and biomagnified along the aquatic ecosystem (through water interactions, sediments and biota along the food chain) are one of the most dangerous contaminant group ${ }^{12}$. Mcrophytes inhabit water and coastal parts of aqatic ecosystems and depending on their morphological and physiological characteristics and ecological adaptability, they can be used as biomonitors or/and phytoremediators ${ }^{13,14}$. Macrophytes can accumulate HM due to the absence of tissue barriers and, depending on the species, environmental conditions and its availability in water and sediment ${ }^{15,16}$. Heavy metal contents in macrophytes represents their presence in aquatic ecosystem during whole life cycle unlike chemical measurements that give information about the current state ${ }^{17}$.

The aim of this study was to compare data from chemical analyses of HM concentrations in water, suspended solids and sediment with HM contents in native macrophytes, Myriophyllum spicatum (Eurasian watermilfoil, spike watermilfoil), and Potamogeton pusillus, (small pondweed, lesser pondweed or least pondweed), in reservoirs of Hydro Power Plant (HPP) Bajina Bašta and Zvornik, on River Drina in Serbia.

\section{Material and Methods}

Samples for analyses were taken in October 2015 from water, suspended solids, sediment and macrophytes at locations: reservoir of HPP Zvornik, 200 m upstream of the dam ( $N 4^{\circ} 2^{\prime} 24.81^{\prime \prime}$; $\mathrm{E}$ $\left.19^{\circ} 06^{\prime} 10.07^{\prime \prime}\right)$ and reservoir of HPP Bajina Bašta, $200 \mathrm{~m}$ upstream of the dam; (N $43^{\circ} 58$ '03.35"; E 19 24 ' 11.14") on middle course of Drina river (Fig.1), according to ISO 5667-6, EN ISO 5667-3: 2007, ISO 5667-12 methods. The water samples were collected in the plastic bottle of $200 \mathrm{ml}$. The sampling was used Grab sampler (dredge) for taking sediment surface. Sediment samples were collected in glass jars. Suspended sediment sampled as a composite of the depth of the pump PTP-150 Portable Pump. All samples are transported to the laboratory stored on $4^{\circ} \mathrm{C}$. After filtering a water sample, the particles are dried and weighed to determine suspended solids. Plant materials were collected by hand form area of $1 \mathrm{~m}^{2}$ in 3 repetitions, $1-3 \mathrm{~m}$ from the waterside. The collected plant material was dried and, in December 2015, a parent solution for the analysis of heavy metals was prepared. Results are shown as average \pm standard deviation (SD). 


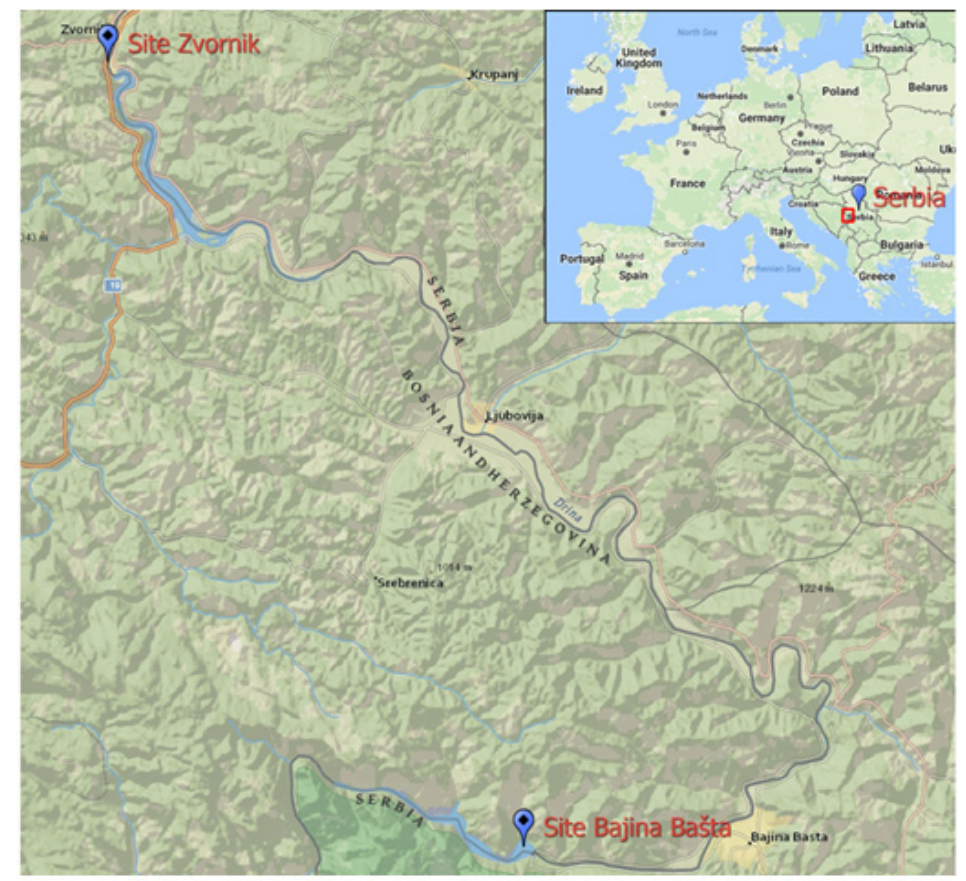

Fig. 1: Sample collections sites at River Drina in Serbia. Source: SASplanet 160707, ESRI ArcGIS. NatGeo \& Google Map (GoogleMapMaker)

The samples were analysed for: $\mathrm{Zn}, \mathrm{Cd}, \mathrm{Cu}, \mathrm{Pb}, \mathrm{Cr}$, As (EPA7000b), and $\mathrm{Ni}$ (EPA7010), and $\mathrm{Hg}(\mathrm{H} 1.004)$ in accredited laboratory. For determining the content of $\mathrm{Cd}, \mathrm{Cr}, \mathrm{Cu}, \mathrm{Ni}, \mathrm{Pb}, \mathrm{Zn}$, As and $\mathrm{Hg}$ in the sediment, suspended solids and plant material was applied flame atomic absorption spectrophotometry AAS (Perkin Elmer Analyst 700), by prior microwave digestion of samples (EPA 3051) with aqua regia $\left(\mathrm{HCl}+\mathrm{HNO}_{3}, 3: 1\right)$ and filtration. Results for metal content are calculated on the dry weight of sediment, suspended solids and plants. The concentration of metal in water was determined by means of inductively coupled plasma mass spectroscopy (ICP-MS, Perkin Elmer ELAN 5000).

The results of analysis were compared with regulated values Regulation on limit values of pollutants in surface and ground waters and sediments and deadlines for their achievement, Regulation on limit values for priority and priority hazardous substances that pollute surface water and deadlines for their achievement, Regulation on parameters ecological and chemical status of surface waters and the parameters of the chemical and groundwater quantitative status (Official Gazette Republic of Serbia, nos. 50/2012, 24/2014, and 74/2011), based on maximum allowable concentrations of pollutants (MAC) and remediation values (RV).

\section{Results}

Contents of HM in water were below the limit of detection of the applied methods (Tab.1) and below the limit values so that belongsto class I. These waters, in the natural state or after disinfection, can be used for any purposes, even to supply the

Table 1: Heavy metal contents in water

\begin{tabular}{llll}
\hline Metals & Unit & Z & BB \\
\hline $\mathrm{Ni}$ & $\mathrm{mg} / \mathrm{kg}$ & $<0.001$ & $<0.001$ \\
$\mathrm{Zn}$ & $\mathrm{mg} / \mathrm{kg}$ & $<0.023$ & $<0.023$ \\
$\mathrm{Cd}$ & $\mathrm{mg} / \mathrm{kg}$ & $<0.0002$ & $<0.0002$ \\
$\mathrm{Cr}$ & $\mathrm{mg} / \mathrm{kg}$ & $<0.0004$ & $<0.0004$ \\
$\mathrm{Cu}$ & $\mathrm{mg} / \mathrm{kg}$ & $<0.0005$ & $<0.0005$ \\
$\mathrm{~Pb}$ & $\mathrm{mg} / \mathrm{kg}$ & $<0.0029$ & $<0.0029$ \\
$\mathrm{As}$ & $\mathrm{mg} / \mathrm{kg}$ & $<0.0013$ & $<0.0013$ \\
$\mathrm{Hg}$ & $\mathrm{mg} / \mathrm{kg}$ & $<0.00016$ & $<0.00016$ \\
\hline
\end{tabular}

Key: Z - reservoir of HPP Zvornik; BB - reservoir of HPP Bajina Bašta 
settlement with drinking water, in the food industry and for the cultivation of precious fish species (Salmonidae). This is in line with the results of official monitoring and analyzes for the previous multiyear period $^{18}$.

Content HM in suspended solids exceeds the limit values for $\mathrm{Ni}, \mathrm{Zn}, \mathrm{Cd}, \mathrm{Cu}$ in Zvornik reservoir and for $\mathrm{Zn}, \mathrm{Cu}$ and $\mathrm{Hg}$ in Bajina Bašta reservoir
(Tab. 2.). For comparison with $\mathrm{MAC}$ and $\mathrm{RV}$, HM contents were corrected by the content of organic matter and clay particules. Concentrations exced remediation values were determined for $\mathrm{Zn}$ in Zvornik reservoir and for $\mathrm{Cu}$ in Bajina Bašta reservoir. The impact of HM in suspended solids in the ecosystem is not crucial, since its content is less than $10 \mathrm{mg} / \mathrm{l}$ of water.

Table 2: Heavy metal contents in suspended solids

\begin{tabular}{rrrrrrr}
\hline HM & $\begin{array}{r}\mathbf{Z} \mathbf{1} \\
\mathbf{m g} / \mathbf{k g}\end{array}$ & $\begin{array}{r}\mathbf{Z} \mathbf{2} \\
\mathbf{m g} / \mathbf{k g}\end{array}$ & $\begin{array}{r}\text { BB 1 } \\
\mathbf{m g} / \mathbf{k g}\end{array}$ & $\begin{array}{r}\text { BB 2 } \\
\mathbf{m g} / \mathbf{k g}\end{array}$ & $\begin{array}{r}\text { MAC } \\
\mathbf{m g} / \mathbf{k g}\end{array}$ & $\begin{array}{r}\mathbf{R V} \\
\mathbf{m g} / \mathbf{k g}\end{array}$ \\
\hline $\mathrm{Ni}$ & 61.1 & 184 & 17.9 & 54.9 & 35 & 210 \\
$\mathrm{Zn}$ & 1460 & 3233 & 560 & 1048 & 480 & 720 \\
$\mathrm{Cd}$ & 0.0029 & 0.0042 & 0.0011 & 0.0012 & 0.002 & 0.012 \\
$\mathrm{Cr}$ & 72.4 & 136 & 265 & 502 & 380 & 380 \\
$\mathrm{Cu}$ & 84.4 & 157 & 269 & 402 & 36 & 190 \\
$\mathrm{~Pb}$ & 0.241 & 0.357 & 0.480 & 0.627 & 0.530 & 0.530 \\
$\mathrm{As}$ & 36.7 & 59.5 & $<0.064$ & - & 55 & 55 \\
$\mathrm{Hg}$ & 0.43 & 0.60 & 1.69 & 2.24 & 0.5 & 10 \\
\hline
\end{tabular}

Key: 1 - measured value, 2 - corected value, MAC - maximal aloivable concentration; $\mathrm{RV}$ - remediation value, Z - reservoir of HPP Zvornik; BB - reservoir of HPP Bajina Bašta

Contents of $\mathrm{HM}$ in sediment of Zvornik reservoir in Bajina Bašta reservoir none of the parameters exceed MAC for Ni, Zn, Cd, Pb and As (exceed RV), $\quad$ tested exceeds the MAC (Table 3.).

Table 3: Heavy metal contents in sediment

\begin{tabular}{lrrrrrr}
\hline $\mathbf{H M}$ & $\begin{array}{r}\mathbf{Z} \mathbf{1} \\
\mathbf{m g} / \mathbf{k g}\end{array}$ & $\begin{array}{r}\mathbf{Z} \mathbf{2} \\
\mathbf{m g} / \mathbf{k g}\end{array}$ & $\begin{array}{r}\text { BB 1 } \\
\mathbf{m g} / \mathbf{k g}\end{array}$ & $\begin{array}{r}\text { BB 2 } \\
\mathbf{m g} / \mathbf{k g}\end{array}$ & $\begin{array}{r}\text { MAC } \\
\mathbf{m g} / \mathbf{k g}\end{array}$ & $\begin{array}{r}\mathbf{R V} \\
\mathbf{m g} / \mathbf{k g}\end{array}$ \\
\hline $\mathrm{Ni}$ & 47.6 & 68.5 & 31 & 41.6 & 35 & 210 \\
$\mathrm{Zn}$ & 593 & 811 & 129 & 151 & 480 & 720 \\
$\mathrm{Cd}$ & 0.0020 & 0.0025 & 0.0001 & 0.0001 & 0.002 & 0.012 \\
$\mathrm{Cr}$ & 40.7 & 51.7 & 20.4 & 24.8 & 380 & 380 \\
$\mathrm{Cu}$ & 22.2 & 29.2 & 17.5 & 18.9 & 36 & 190 \\
$\mathrm{~Pb}$ & 0.106 & 0.128 & 0.003 & 0.004 & 0.530 & 0.530 \\
$\mathrm{As}$ & 87.1 & 109 & 1.43 & 1.52 & 55 & 55 \\
$\mathrm{Hg}$ & 0.41 & 0.48 & 0.22 & 0.24 & 0.5 & 10 \\
\hline
\end{tabular}

Key: 1 - measured value, 2 - corected value, MAC - maximal aloivable concentration; $\mathrm{RV}$ - remediation value, $\mathrm{Z}$ - reservoir of HPP Zvornik; BB - reservoir of HPP Bajina Bašta 
Potamogeton pusillus were collected at Zvornik reservoir and Myriophyllum spicatum at Bajina Bašta reservoir. The results of chemical analyze indicate the degree of contamination of the site: Zvornik $\mathrm{Pb}$, $\mathrm{Cu}, \mathrm{As}$, Bajina Bašta $\mathrm{Pb}, \mathrm{Cu}, \mathrm{Ni}$ (Tab. 4.).

In all the examined cases $\mathrm{HM}$ content in macrophytes were higher than in water and relationship with suspended solids and sediment depends to plant species and metal. For $\mathrm{Ni}, \mathrm{Cd}$ and As accumulation was obseved only in Myriophyllum spicatum, for $\mathrm{Cu}$ and $\mathrm{Pb}$ in both types.

Potamogeton pusillus avoids accumulation of $\mathrm{Ni}$, $\mathrm{Zn}, \mathrm{Cr}$ and $\mathrm{As}$, while the concentration of $\mathrm{Cd}$ and $\mathrm{Cu}$ is close to their concentration in suspended solids and sediment. Myriophyllum spicatum avoids Zn, $\mathrm{Ni}$ from sediment, $\mathrm{Cr}$ from suspended solids, while the concentration of $\mathrm{Cd}$ and $\mathrm{Pb}$ is similar to that of suspended solids.

Table 4: Heavy metal contents in macrophytes

\begin{tabular}{lllllll}
\hline $\mathbf{H M}$ & $\begin{array}{l}\mathbf{Z} \\
\mathbf{m g} / \mathbf{k g}\end{array}$ & $\mathbf{M} / \mathbf{S S}$ & $\mathbf{M} / \mathbf{S}$ & $\begin{array}{l}\text { BB } \\
\mathbf{m g} / \mathbf{k g}\end{array}$ & $\mathrm{M} / \mathrm{SS}$ & $\mathrm{M} / \mathrm{S}$ \\
$\mathrm{Ni}$ & $3.40 \pm 1.03$ & 0.06 & 0.07 & $46.28 \pm 9.77$ & 2.59 & 0.11 \\
$\mathrm{Zn}$ & $1.35 \pm 0.33$ & 0.00 & 0.00 & $0.23 \pm 0.04$ & 0.00 & 0.01 \\
$\mathrm{Cd}$ & $0.0019 \pm 0.00042$ & 0.67 & 0.95 & $0.00095 \pm 0.00012$ & 0.89 & 7.91 \\
$\mathrm{Cr}$ & $8.23 \pm 1.12$ & 0.11 & 0.20 & $30.22 \pm 8.96$ & 0.11 & 1.48 \\
$\mathrm{Cu}$ & $106.4 \pm 0.26$ & 1.26 & 4.77 & $117.75 \pm 43.2$ & 0.44 & 6.73 \\
$\mathrm{~Pb}$ & $0.621 \pm 0.208$ & 2.58 & 5.86 & $0.425 \pm 0.112$ & 0.89 & 123.21 \\
$\mathrm{As}$ & $19.68 \pm 2.77$ & 0.54 & 0.23 & $3.12 \pm 0.96$ & - & 2.18 \\
$\mathrm{Hg}$ & $<0.5$ & - & - & $<0.5$ & $>1$ & - \\
\hline
\end{tabular}

Key: M/SS - ratio of HM concentrations in macrophytes to HM concentration in suspended solids, $\mathrm{M} / \mathrm{S}$ - ratio of $\mathrm{HM}$ concentrations in macrophytes to $\mathrm{HM}$ concentration in sediment, $\mathrm{Z}$ - reservoir of HPP Zvornik; BB - reservoir of HPP Bajina Bašta

\section{Discussion}

The indicator function of macrophytes is increasingly being emphasized in ecological research, because the content of an element in the plant tissue is an indicator of its presence in the aquatic environment. Submerged species have a particularly pronounced ability to accumulate chemical elements from the aquatic environment so that the concentration of individual elements in their tissue can be 10 , 100 or several thousand times higher than their concentration in the external environment ${ }^{19,20}$. Therefore, the role of macrophytes in the circulation of heavy metals in aquatic ecosystems is irreplaceable. This circulation takes place in two ways: directly by the bioaccumulation of metals, and indirectly by slowing down the flow of water, which leads to faster sedimentation of dispersed particles with metal ions. Aquatic macrophytes do not have regulatory mechanisms in regarding of the absorption of nutrients and heavy metals, and therefore their influence on the external environment is manifested through processes of bioconcentration of chemical elements, and the increased accumulation of nutrients and metals in their tissue is most often due to their increased concentration in the aquatic environment ${ }^{21,22}$. The results of our research indicate the bioaccumulation of all HM investigated in relation to water, as well as the sedimentation from suspended solids ( $\mathrm{Pb}$ in Zvornik reservoir and $\mathrm{Ni}$ in Bajina Bašta reservoir).

Biomonitoring of presence of heavy metals using macrophytes has the advantage of providing timely integrated information on the quality of aquatic ecosystems ${ }^{19,20}$. The rate of accumulation of heavy metals in macrophytes depends on plant species, the type of metal and its concentration, as well as the physicochemical properties of water that determine the bioavailability of HM. In the accumulation HPP Bajina Bašta, Miriophillum spicatum accumulates every metal except arsenic, Ni through concentrations in suspended application and sediment. In the accumulation HPP Zvornik 
Potamogeton pusillus, $\mathrm{Pb}$ accumulates even over concentration in suspended solids and sediment. Potamogeton and other types of macrophytes that naturally inhabit aquatic ecosystems can absorb heavy metals throughout root, sediment and / or water from out of water and suspended so that they are very suitable for monitoring bio-available heavy metals ${ }^{23}$.

The absence of significant correlations between HM content in water, sediment, suspended solids and macrophytes can be explained by access to research: physicochemical analyzes of HM content in water, suspended solids and sediment are based on current samples and refer to the total content of $\mathrm{HM}$ while they dont show any information about previous condition. Sampling was carried out in October when the water levels and flows are low as a result of climatic conditions during the summer (low precipitation), which cause poor erosion of the surrounding terrain and low the HM leaching. The macrophytes examined during this period of the year at the end of intensive growth and the HM content in them indicates their presence in bioavailable forms in the previous period (at least from the beginning of the vegetative period). Since only bioavailable forms of HM enter food chains where they can demonstrate their toxicity to assess the condition of aquatic ecosystems, they are a more suitable parameter than their overall content1. The low availability of heavy metals in the river system could be due to the flow and its rate compares to stagnant lake system. In case of HPP reservoirs conditions also include flow and stagnation, which makes it difficult to interpret experimental data. The macrophyte concentration of highly toxic metals like - $\mathrm{Cr}, \mathrm{Cd}$ and $\mathrm{Pb}$ were usually lower compared to the essential metals like $\mathrm{Fe}, \mathrm{Mn}, \mathrm{Ni}$ and $\mathrm{Zn}^{24}$. In river Drina of heavy metals concentrations in plants was the highest for $\mathrm{Pb}$ which may indicate some transient anthropogenic pollution not detected by tests of the current state of water, suspended solids and sediment.

The obtained results indicate the need for further monitoring of the concentration of heavy metals in macrophytes, as well as suspended solids and sediment, in order to indicate and assess the quality of the aquatic ecosystems for the sake of sustainable development. For the next period, the macrophyte atlas in the Drina River Basin can be recommended, with the analysis of the heavy metal content, which would provide integral data and time and spatial distribution of these pollutants.

\section{Acknowledgements}

This research was supported by the Electric Power Industry of Serbia (Study on the degradation processes in reservoirs and flow of the River Drina and balancing pollution)

\section{References}

1. Sharma, V., Walia, Y. K., Kumar, A., Assesment of Physico Chemical Parameters for analysing Water: A Rewiev. Journal of Biological and Chemical Chronicles, 2(1): 25-33 (2015)

2. Jørgensen, S.E., Ecohydrology as an important concept and tool in environmental management. Ecohydrology \& Hydrobiology, 16(1): 4-6 (2016)

3. Rashidi, M. N., Begum, R. A., Mokhtar, M., and Jacqueline, J., Criteria towards Achieving Sustainable Construction Through Implementation of Environmental Management Plan (EMP). Advanced Review on Scientific Research, 1(1): 43-64 (2014)

4. Muhar, S., Januschke, K., Kail, J., Poppe, M., Schmutz, S., Hering, D., Buijse, A. D., Evaluating good-practice cases for river restoration across Europe: context, methodological framework, selected results and recommendations. Hydrobiologia 769:319 (2016)

5. Schiemer, F., Building an eco-hydrological framework for the management of large river systems. Ecohydrology \& Hydrobiology 16 19-25 (2016)

6. Ivanovic, Z., Jabucar, D., Milic, N., Simjanovic, V., Topalovic, Z., Pollution in the Drina River Basin An inventory of potential sources, Ed. Ignjatovic J. The Regional Environmental Center for Central and Eastern Europe (REC) (2011)

7. Prohaska, S., Simic, Z., Orlic, A., Ristic, V., Basic hydrographic and hydrologic characteristics of the Drina river basin and 
weather data. Waterpower Engineering, 207208: 21-38 (2004)

8. Matic, B. B., Simic, Z., Comparison of Pre and Post Development Low Flow Conditions for Drina River. Procedia Engineering 162: $284-292(2016)$

9. Dragicevic, S., Tosic, R., Stepic, M., Zivkovic, N., Novkovic, I., Consequences of the River Bank Erosion in the Southern Part of the Pannonian Basin: Case Study - Serbia and the Republic of Srpska. Forum Geografic, Craiova 12.1: 5-15 (2013)

10. Damo, R., Icka, P., Evaluation of Water Quality Index for Drinking Water. Polish Journal for Environtal Studies, 22(4): 1045-1051 (2013)

11. Pajevic, S. P., Vucovic, M. S., Kevrešan, Ž. S., Matavulj, M. N., Radulovic, S. B., Radnovic, D.V., Aquatic Macrophytes as Indicators of Heavy Metal Pollution of Water in DTD Canal System. Proceedings for Natural Sciences, Matica Srpska Novi Sad, 104: 51-60 (2003)

12. Massoudieh, A., Bombardelli, F.A., Ginn, T. R., A biogeochemical model of contaminant fate and transport in river waters and sediments. Journal of Contaminant Hydrology, 112: 103117 (2010)

13. Materac, M., Wyrwicka, A., Sobiecka, E., Phytoremediation techniques in wastewater treatment. Environmental Biotechnology, 11(1): 10-13 (2015)

14. Monferrána, M. V.,Pignatab, M. L., Wunderlin, D.A., Enhanced phytoextraction of chromium by the aquatic macrophyte Potamogeton pusillus in presence of copper. Environmental Pollution, 161(2): 15-22 (2012)

15. Brankovic, S., Pavlovic-Muratspahic, D., Topuzovic, M., Glišic R., Milivojevic, J., Đekic, V., Metals concentration and accumulation in several aquatic macrophytes. Biotechnology and Biotechnological Equipment, 26(1): 27312736 (2012)

16. Dhote, S., Dixit, S., Water quality improvement through macrophytes- a review. Environmental Monitoring and Assessment, 152(1): 149-153 (2009)
17. Kang, J. H., Lee, Y. G., Lee, K. Y., Cha, S. M., Cho, K. H., Lee, Y.S., Ki, S.J., Yoon, I. H., Kim, K. W. \& Kim, J. H., Factors affecting metal exchange between sediment and water in an estuarine reservoir: A spatial and seasonal observation, Journal of Environment Monitoring, 11: 2058-2067 (2009)

18. Lešcešen, I., Pantelic, M., Dolinaj, D., Stojanovic, V., Miloševic, D., Statistical analysis of water quality parameters of the Drina river (West Serbia), 2004-11. Polish Journal for Environtal Studies, 24(2): 555-561 (2015)

19. Ravera, O., Cenci, R., Beon, G. M., Dantas, M., Lodigiani, P., Trace element concentrations in freshwater mussels and macrophytes as related to those in their environment. Journal of Limnology, 62(1): 61-70 (2003).

20. Baldantoni, D., Maisto, G., Bartoli, G., Alfani, A., Analyses of three native aquatic plant species to assess spatial gradients of lake trace element contamination. Aquatic Botany, 83: 48-60 (2005)

21. Yurukova, L., Kochev, H., Heavy metal concentrations in main macrophytes from the Srebarna Lake along the Danube (Bulgaria). 31 Conference of IAD, Baja - Hungary, Scientific Papers. Limnology Reports Danube, Part I: 195-200 (1996)

22. Stankovic, Ž., Pajevic, S., Vuckovic, M., Stojanovic, S., Concentrations of Trace Metals in Dominant Aquatic Plants of the Lake Provala (Vojvodina, Yugoslavia). Biologia Plantarum, 43 (4): 583-585 (2000)

23. Lewander, M., Greger, M., Kautsky, L., Szarek, E., Macrophytes as indicators of bioavailable $\mathrm{Cd}, \mathrm{Pb}$ and $\mathrm{Zn}$ flow in the river Przemsza, Katowice Region. Applied Geochemistry, 11: 169-173 (1996)

24. Venkatesha, R. K., Somashekar, R. K., Prakash, K. L., Biomonitoring of Metals in Freshwater Macrophytes and Benthic Organisms. International Journal of Innovative Research in Science, Engineering and Technology, 2 (9): 4661-4670 (2013) 